\title{
An Environmental Education and Communication Project on Migratory Fishes and Fishing Communities
}

\author{
Sara Costa Carvalho ${ }^{1,2, *}$, Heitor Oliveira Braga ${ }^{1,2,3} \mathbb{D}^{\mathbb{D}}$, Sofia de Santa-Maria ${ }^{2}$, Beatriz Fonte ${ }^{2}$, \\ Mário Jorge Pereira ${ }^{1,2}$, Antonio García-Vinuesa ${ }^{4}(1)$ and Ulisses Miranda Azeiteiro ${ }^{1,2}$ \\ 1 Centre for Environmental and Marine Studies (CESAM), Campus Universitário de Santiago, \\ University of Aveiro, 3810-193 Aveiro, Portugal; heitorob@ua.pt (H.O.B.); mverde@ua.pt (M.J.P.); \\ ulisses@ua.pt (U.M.A.) \\ 2 Department of Biology, Campus Universitário de Santiago, University of Aveiro, 3810-193 Aveiro, Portugal; \\ sofiasm99@ua.pt (S.d.S.-M.); beatrizfonte@ua.pt (B.F.) \\ 3 CAPES Foundation, Ministry of Education of Brazil, Brasília 70040-020, Brazil \\ 4 SEPA-Interea Research Group, Department of Educational Sciences, \\ Universidade de Santiago de Compostela, 15782 Santiago de Compostela, Spain; a.garcia.vinuesa@usc.es \\ * Correspondence: saradcarvalho@ua.pt
}

check for

updates

Citation: Carvalho, S.C.; Braga, H.O.; de Santa-Maria, S.; Fonte, B.; Pereira,

M.J.; García-Vinuesa, A.; Azeiteiro,

U.M. An Environmental Education and Communication Project on Migratory Fishes and Fishing Communities. Educ. Sci. 2021, 11, 337. https://doi.org/10.3390/

educsci11070337

Academic Editor: Eila Jeronen

Received: 31 May 2021

Accepted: 29 June 2021

Published: 6 July 2021

Publisher's Note: MDPI stays neutral with regard to jurisdictional claims in published maps and institutional affiliations.

Copyright: (c) 2021 by the authors. Licensee MDPI, Basel, Switzerland. This article is an open access article distributed under the terms and conditions of the Creative Commons Attribution (CC BY) license (https:/ / creativecommons.org/licenses/by/ $4.0 /)$.

\begin{abstract}
This study aims at evaluating the environmental education (EE) and communication intervention for the valorization of migratory fish resources in an estuary of northern Portugal. The EE component intervention was implemented among Middle School pupils of that region. Students' knowledge was quantitatively evaluated with an experimental approach of pre-testing and posttesting, on the ocean and estuarine literacy (OEL) and biology of migratory species, such as sea lamprey. This study also analyzes the communication component developed via social media. Results of the EE component show an evident increment of OEL $(p<0.05)$. It is also highlighted that students had previous knowledge on issues that are not covered in the curriculum. Social media has shown to be an effective communication tool mostly among the scientific community (e.g., Ethnobiology). The research has various implications to OEL since it brings a new perspective towards the integration of ocean literacy in formal education; as well as the valorization of Students' local ecological knowledge and of inter-generational dynamics. This study contributed to promoting local biodiversity, OEL, and participatory local governance of these ecosystems.
\end{abstract}

Keywords: ocean and estuarine literacy; migratory fishing species; Minho River Estuary

\section{Introduction}

Diadromous migratory fish species that constitute important fishery resources for local fishing communities and local economies [1,2], face threats from the sea, estuaries, and riverine basins [3,4]. Sea lamprey Petromyzon marinus Linnaeus, 1758 and allis shad, Alosa alosa Linnaeus, 1758 are anadromous fish species that migrate from marine to freshwater habitats to spawn and complete their life cycle [4]. Obstructions to spawning migrations through dams are one of the main threats [3-6]. In the geographical area of this studyMinho River Estuary (northern coastal of Portugal and Galicia-Spain) - the construction of the major dams in Minho River coincided with a period of sudden decline for allis shad $[4,5]$.

In the Minho River Region, the sea lamprey fisheries support the local economy and play an important sociocultural role [1,2]. In this area, "Fishers shared a vast informal knowledge of sea lamprey zoology and ecology (... ). This fisher's knowledge becomes essential to preserve cultural practices of the sea lamprey, which is currently highly susceptible to anthropogenic pressures." [1] (p. 2). Thus, it is of critical importance to preserve this knowledge for future generations and for conservation biology purposes [1,2].

For these above reasons, tackling marine and coastal threats should rest on an Integrated Management of such ecosystems [7] and of fisheries, according to the Objective of 
Sustainable Development 14 (manage of coastal and marine ecosystems services-fish and other marine goods' consumption) of the United Nations' Agenda 2030 [8]. Participatory management, (e.g., the Mondego River [9], where "fishers, scientists and authorities annually meet to update data for anadromous fish and rules for the upcoming fishing season" (p. 1)), is also fundamental for conservation.

An integrated marine and coastal management includes tools such as environmental education (EE) and communication [7], where Ocean Literacy plays a central role, both in formal and informal education [10]. Ocean education "emerges as a logical step towards a more ocean-literate public and enhancing marine citizenship" [11] (p. 98). Ocean education, literacy, marine resources valuation, as well as environmental behavior and attitudes development towards ocean sustainability, ocean stewardship, and marine citizenship are fundamental [11]. The attitude development through participation is also more and more recognized as an EE goal [12].

The Decade of Ocean Science for Sustainable Development (2021-2030) involves several dimensions [13-15], one of which is to have "ocean-literate" citizens and for that purpose "scientists will need to work closely with decision-makers and society" [16] (p. 1). Ocean-literate citizens are also the goal of Ocean literacy as stated by Schoedinger et al. [17] (p. 3): "The Ocean Literacy Campaign is a wide-ranging, collaborative and de-centralized effort by scientists and educators to create a more ocean literate society". Starting with the incorporation of ocean science content into school programs [17], "the focus expanded ( . . . ) to reaching multiple audiences (e.g., business professionals, scientists, policy makers, fishers) through various means (e.g., formal and informal education, Blue Growth strategies)" [18] (p. 1) as well as non-formal education. Resources of non-formal education called Environmental Education Facilities (EEF) such as museums and "aquaria could be a particularly important tool to improve ocean literacy, as participants showed the greatest interest in the ocean when it came to marine animals" [11] (p. 106). EEF are particularly useful tools since they are located close to local communities, which help educators in challenging the hegemonic behavior, by using a socio-critical approach [19]. To illustrate the importance of EEF and connection with formal education, Yen-Ling et al. [20] show that one of students' primary sources of "Marine Knowledge and Ocean Literacy" are museums and for the general public, following Schubel and Schubel [10], are aquariums and other science institutions.

In the Portuguese scope, the National Strategy of Environmental Education (NSEE) 2017-2020, which is currently under review, assumes the valorization of the ocean and coastal territory as a differentiator factor of the country. In this sense, it intends to preserve the riverine ecosystems and a sustainable management of drainage basins [21]. The NSEE also recognizes the increasing importance of EEF like aquariums [21].

Targeting local communities, fishers and scholars from coastal areas and fishing communities preserves an ancestral knowledge $[1,2]$ and heritage (e.g., fishing and food traditions) [22], a culture of sustainability, and literacy for participation and decisionmaking. Regarding fish consumption, Kapelari et al. [23] show the importance of cultural knowledge to understand consumer preferences on food. In this sense, heritage is a key parameter that must be considered in the definitions of food sustainability and in relevant policies at European and world levels [22]. The notion of fish consumption has an implicit cultural identity, such as traditions associated with Atlantic diets. Food, namely, fish goods reaffirm one's own personal and collective heritage of culture and tradition, and provides a feeling of belonging to the environment [24].

The present study involves a school in the Minho River Estuary, and some students are children and/or grandchildren of the local fishermen. Teaching them about the surrounding endogenous bioresources and conservation biology together with the LEK retrieval, documentation, and sharing [1,2] from their parents and grandparents, promotes intergenerational bonds and increments OEL in the young. Fauville et al. [25] "( ... ) described the numerous barriers that inhibit teaching 12-19-year-olds about the ocean" and at the same time mention that "there are resources, courses and network communities allocated to 
marine education to empower educators." [25] (p. 91). Besides, an improved ocean literacy can promote citizenship and bring multiple societal benefits [10].

Concerning networking in scientific knowledge, social media provides contact with the public and can be used to promote Ocean Literacy [26] functioning as a "vector for science communication and outreach" [27] (p. 1). Among teachers, social media also play a crucial role. Mogias et al. [28] observed that Greek Pre-service teachers got " ( . . ) most information on ocean content from the Internet and mass media and less from formal education, nongovernmental organizations, books, and out-of-school settings" [28] (p. 251).

The bibliometric analysis of ocean literacy of Costa and Caldeira [29] evidences the low number of studies in Portugal. Following the few studies on OEL in Portugal [30] and including Portugal [25], and in the context of an educational and communication initiative on Diadromous (Anadromous) species in the Minho River Estuary and local fishing communities [1,2], a two-year intervention was developed. This study is integrated in a larger project in the region-The Cooperminho-and is aimed at investigating the impacts of that intervention in the literacy of Middle School students regarding fish ecology and conservation. Further analyzed is the communication component of the Cooperminho project-the use of Facebook and Instagram social media as sources of information to the public.

\subsection{Study Area}

This study was carried out in the parish of Vila Nova de Cerveira (VNC), district

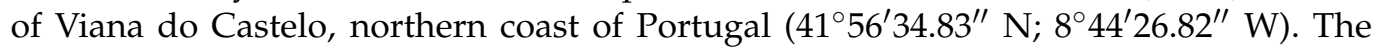
Minho River separates the village of VNC from the city of Góian, province of Pontevedra, Galicia (Northern West Coast of Spain). There are numerous standard features between the Autonomous Region of Galicia and the North of Portugal, especially in the Minho Subregion, ranging from natural to cultural aspects. Traditional symbols of identity include the landscape; the Galician-Portuguese language; the calendar of rural work; rich gastronomy with common elements; and the maritime activity [22].

VNC is $11 \mathrm{~km}$ far from Caminha-the city in the Minho River mouth. The territorial area of the municipality of VNC is $108.47 \mathrm{~km}^{2}$, and the population is 9110 individuals [31]. VNC, in the Minho sub-region, has about 1264 inhabitants and a territorial area of $3.32 \mathrm{~km}^{2}$ [32]. VNC village is known for its culture, gastronomy, and peculiar artisanal fishing communities [1,2,32]. Migratory species such as sea lamprey Petromyzon marinus and allis shad Alosa alosa represent an important fishery resource [1,2].

In VNC, there is an aquamuseum - an environmental education facility (EEF) for informal training and awareness. Aquamuseu do Rio Minho stimulates and disseminates the cultural and natural framework associated with this freshwater ecosystem [33]. It is a public property instrument, in a partnership between the City Council and the University of Porto (EEF also valued as a research center in biology and aquatic ecosystems). Having a collection of fishing gear, traditions, an aquarium, and an otter spot that simulates the ecosystem of Minho River, the Aquamuseu has a program of visits and activities, namely, for scholars [33].

The educative interventions were performed at a middle and secondary school-Escola Básica e Secundária de Vila Nova de Cerveira, located in an urban context of Minho River. This school is a public educational institution with a wide range of levels of education and teaching. It includes pre-school education, regular basic education with the 1st, 2 nd, and 3rd cycles (primary and middle), and secondary education [34]. This public school has 570 students, distributed by the 2nd (178 students) and 3rd (239 students) cycles/level of basic education (respectively in primary and middle school) and secondary education level (153 students) [35].

\subsection{The Cooperminho}

Running until March 2021, the Cooperminho project integrated the measure "Promoting Sustainable, Efficient, Innovative and Competitive Fishing", in the "Innovation and 
Knowledge" Action, and in the Intervention "Partnerships between Scientists and Fishermen", aiming at the valorization of the fish resources of the Minho River and associated socio-cultural heritage always promoting the sustainability of the exploited resources.

The environmental education (EE) and communication dimensions of Cooperminho project were of utmost importance. Although the project embraces other components, such as the technical process of fish' traceability in the Minho River and the study of consumers' preferences on fishing products, the EE component is the one directly related to ocean literacy.

\section{Methodology}

Both the environmental education component and the communication components of the study used a quantitative methodology and were carried out for two consecutive years (2019 and 2020).

\subsection{Environmental Education}

The methodological instrument of the Environmental Education (EE) component was a quantitative approach of experimental type [36]. The aim of this methodological design is to assess to what extent the intervention on ocean and estuarine literacy impact participants' learning. Within the experimental type, the typology of pre-experiments-pre-test and posttest with one group [37] — was used i.e., delivering a test before the educational intervention (a 45-min interactive lecture) and the same test after that intervention, according to the objective of the study - evaluating the impact of the lecture on local diadromous ecology.

The component of EE was carried out for two years at the Middle and Secondary School of Vila Nova de Cerveira. A total of 156 students from the 8th grade were involved in the EE intervention. In the first year, two sessions of lectures were developed-the 1st session with theory on migratory fish ecology and human pressures; the 2nd session aimed to teach the students the Ethnobiology component of the Cooperminho project (developed with the local fishing community) and to give feedback and discuss the test results made in the 1st session. The second year planned a field trip to the Minho River, and two visits to the ECOMAR (University of Aveiro) and to the Aquamuseu do Rio Minho. These activities aimed at complementing the intervention, as an interconnectivity praxis and to vale students' knowledge (pre-test and post-test).

After the students finished the pre-test, they attended the theoretical section named "Bioecology and Conservation of anadromous migratory fish-anthropic impacts and climate change". The theoretical section focused on some subjects that are not part of the school curriculum, such as Minho River's biodiversity; Fisheries Biology; Ecology and Conservation; Anadromous and Catadromous species; biology of the sea lamprey, Petromyzon marinus Linnaeus, 1758, allis shad, Alosa alosa Linnaeus, 1758 and others species; sustainable fisheries; local ecological knowledge (LEK) and students' local knowledge, as well as the fish bioecological and environmental threats (namely with dams and passage mechanisms). The content of the test was composed of multiple-choice questions.

The second test was applied immediately after the intervention. By reducing the time between the pre-test and post-test, it was possible to minimize the risk of internal invalidity of the method, since the factor tiredness/lack of concentration of the students could bias the results of the experiment. The validity of the test's content was assured by the state of art [37], in OEL and migratory species ecology and threats. Data were analyzed with the support of the SPSS Program v25. To estimate reliability, Miller et al. [38] were consulted by conducting a flit-half method. We obtained the following values of internal consistency: $\alpha \mathrm{PRE}=0.61$ and $\alpha \mathrm{POST}=0.79$. Following Qaqish [39], these values mean an acceptable and a good internal consistency respectively, considering that this instrument is an educational assessment. The test's protocol was validated by professionals and academics in Environmental Education and Marine Biology's area. This instrument of data collection was also pretested with 15 students from a separate coastal Area in Aveiro Lagoon (Aveiro, Central Portugal). 
To determine if the educational intervention had an effect and what level it had, descriptive analysis was carried out with parametric and non-parametric tests (ANOVA and Pearson Chi-square). The 13 items from the responses were coded with a value of 1 for the correct answer and a value of 0 for the incorrect answers, establishing a value of 13 as the maximum score. To facilitate data interpretation, a variable relating to a weighted total base score of 10 was established $(0,10)$.

\subsection{Communication (Social Media)}

At the beginning of the Cooperminho project, two pages were created on Facebook and Instagram (- @ cooperminho). The pages were intended to share and provide the local community of Vila Nova de Cerveira (students, fishermen, education professionals, and other local people) with Cooperminho activities and information on all the environmental education intervention processes developed in the region. Table 1 summarizes the subthemes (categories of subjects) of the posts in the social media, in particular Facebook.

Table 1. Sub-themes and contents of the Cooperminho Project on Facebook.

\begin{tabular}{|c|c|}
\hline Sub-Themes & Examples of Contents/Events on Facebook \\
\hline Disclosure of events & $\begin{array}{l}\text { The Project and the Aquamuseu } \\
\text { Participation in national and international conferences } \\
\text { Celebrations (e.g., Fisherman's Day; gastronomic festivals) } \\
\text { Calls to the ethnographic collection of local fisheries } \\
\text { (photographs, reports, etc.) }\end{array}$ \\
\hline Ecology of migratory species & $\begin{array}{l}\text { Ecology of the shad } \\
\text { Ecology of the sea lamprey }\end{array}$ \\
\hline $\begin{array}{l}\text { Sociocultural and economic } \\
\text { aspects } \\
\text { Ethnobiology } \\
\text { Historical ecology } \\
\text { Announcements }\end{array}$ & $\begin{array}{l}\text { Preliminary results on the interviews with fishermen about } \\
\text { migratory species } \\
\text { Description of the "Algerife" fishing gear } \\
\text { Advertisements on recreational fishing in the Minho River } \\
\text { (e.g., context of the COVID } 19 \text { pandemic) } \\
\text { Presentations and Publications with description notes } \\
\text { Historical facts about lamprey fishing } \\
\text { Testimonies from fishermen about the stock of lamprey due } \\
\text { to the closure of restaurants (COVID 19) and announcement } \\
\text { of the resumption }\end{array}$ \\
\hline Educational Intervention & $\begin{array}{l}\text { Activities with the middle School of VN Cerveira } \\
\text { Intervention announcements } \\
\text { Description of the intervention ( } 2 \text { sessions) }\end{array}$ \\
\hline Project Products & $\begin{array}{l}\text { Dissemination of books: "Peixes do Rio Minho: Receitas com } \\
\text { História"; children's book "The adventures of the wise Eel and } \\
\text { her friend Lamprey" } \\
\text { Dissemination of scientific illustration contest "Rio Minho, } \\
\text { biodiversity and fishing gear" }\end{array}$ \\
\hline
\end{tabular}

Communications presented by the Cooperminho group in international and national congresses and publications were posted (Table 1). Data on the biology, ecology, and ethnobiology of the sea lamprey, Petromyzon marinus Linnaeus, 1758 and allis shad, Alosa alosa Linnaeus, 1758 were also shared. There were a set of videos published on the various components of the Cooperminho project, of the educational scenario, and news of the fishing activity. The publication process covered the period from December 2018 to May 2020. Subsequently, the communication impact of the two social networks was analyzed in the VNC region, as well as worldwide.

Quantitative anonymous data from visits (followers' likes and clicks) of social networks were exported from the Facebook (www.facebook.com (accessed on 6 May 2020)) and Instagram (www.instagram.com (accessed on 8 May 2020)) platforms in spreadsheets where they were organized and analyzed in Microsoft Excel Office 365 MSO. 


\section{Results}

\subsection{Environmental Education}

To compare the results between the pre-test and the post-test and check if there are any statistically significance results between the knowledge declared before and after the educational intervention, the results of analysis of variance ANOVA and Pearson Chisquare test are presented. There are several reasons to offer the results of these two tests:

- The total variable meets three of the four requirements for using parametric test: It meets the principle of homogeneity (of variances); the sample is greater than 30 and it is a scale; however, the values of the variable are not normally distributed, according to the Shapiro-Wilk test results;

- However, following Luepsen [40], parametric tests (ANOVA) offer similar robustness to non-parametric tests (Pearson Chi-square) with variables not normally distributed.

The results offered of the two statistical tests strengthen and deepen the outcomes obtained. The statistical values presented at Table 2 offer improvements greater than 3 points in 10 after the educational intervention, with more than half of the participants obtaining values greater than 8.46 points (median). Minimum and maximum scores also increased considerably after the lecture. Following this, analysis results from ANOVA and Chi-Square are presented to explore differences between pre-test and post-test.

Table 2. Descriptive statistics.

\begin{tabular}{cccccc}
\hline & Mean & Median & SD & Min. & Max. \\
\hline Pre-test & 4.87 & 4.61 & 2.00 & 1.54 & 8.46 \\
Post-test & 7.89 & 8.46 & 1.53 & 4.62 & 10 \\
\hline
\end{tabular}

To perform Pearson Chi-square test, the scores were grouped according to the categories presented in Table 3, and a pre- and post- tests comparison is shown in Figure 1 in addition to test results.

Table 3. Categories established for applying the Pearson's chi-square test.

\begin{tabular}{cc}
\hline Category & Weighting $\mathbf{1 0}$ \\
\hline Does not satisfy & $<5.00$ \\
Satisfy & {$[5.00,6.99]$} \\
Good & {$[7.00,8.99]$} \\
Great & {$[9.00,10.00]$} \\
\hline
\end{tabular}

Figure 1 shows the percentages of the final assessment according to the categories established in Table 3 where there is an improvement in knowledge after the educational intervention. Analysis of the results offered statistical significance for $\alpha<0.001$.

The comparison of the pre-test and post-test, item by item (question), can be observed in Figure 2. Table 4 shows ANOVA test result in which all the items show an improvement regarding correct answers between pre-test and post-test and most of them presented statistical significance results $(\alpha<0.05)$. 
Final assessment: Pre-test vs Post-test results

$60 \%$
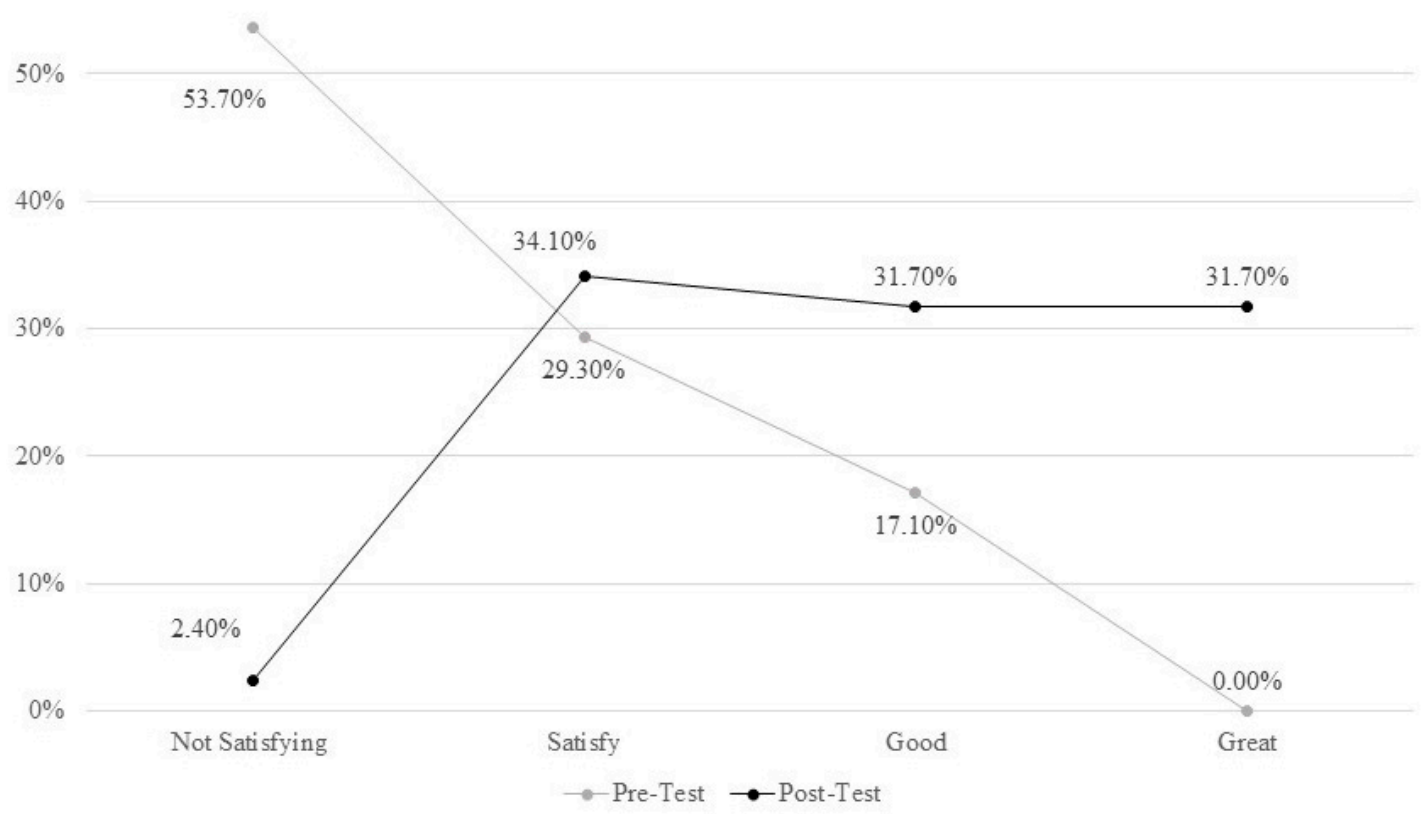

Figure 1. Final assessment of the pre-test and post-test results. Pearson's Chi-square test (value $=34,128 ; \mathrm{df}=3 ; p<0.05$ ) offered statistically significance differences for $\alpha<0.001$.

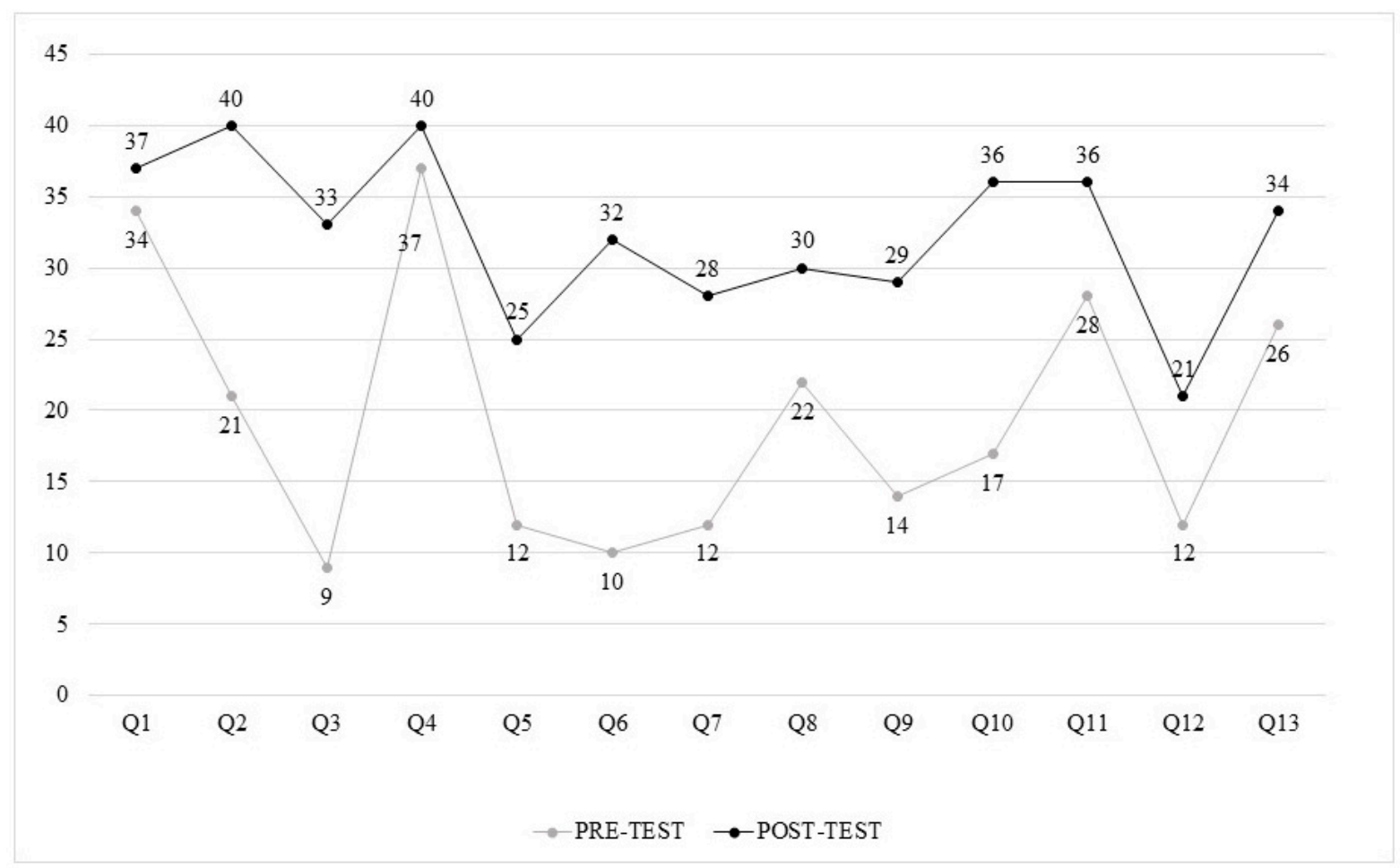

Figure 2. Comparison between the number of correct answers of the pre-test and post-test in basis of the item number. $n=41$. 
Table 4. Variance analysis (ANOVA) results by item-pre-test and post-test comparison.

\begin{tabular}{cccccccc}
\hline & \multicolumn{3}{c}{ ANOVA } & & \multicolumn{3}{c}{ ANOVA } \\
Item & $\mathbf{d f}$ & $\mathbf{F}$ & Sig. & Item & gl & F & Sig. \\
\hline Q1 & 1 & 0.933 & 0.337 & Q8 & 1 & 3.422 & 0.068 \\
Q2 & 1 & 31.391 & $<0.001$ & Q9 & 1 & 12.397 & 0.001 \\
Q3 & 1 & 41.739 & $<0.001$ & Q10 & 1 & 24.558 & $<0.001$ \\
Q4 & 1 & 1.915 & 0.170 & Q11 & 1 & 4.706 & 0.033 \\
Q5 & 1 & 9.037 & 0.004 & Q12 & 1 & 4.219 & 0.043 \\
Q6 & 1 & 5.339 & 0.023 & Q13 & 1 & 4.076 & 0.047 \\
Q7 & 1 & 14.382 & $<0.001$ & & & & \\
\hline
\end{tabular}

Note. Variance analysis (ANOVA) for $p<0.01$.

By observing Figure 2, in all items $(Q)$, the number of correct answers increases after the intervention. Table 4 shows the statistical significance values comparing the results of the pre-test and post-test, item by item. Q3, Q6, Q7, and Q9 show a higher difference of knowledge before and after the educational intervention. Question 3 ('Lamprey lives ... :') was the question with the lowest number of correct answers before the intervention (9 of 41). However, it was the question with the biggest difference between the number of correct answers before and after the intervention, with an increase of 24 students.

Nevertheless, Q1, Q4, and Q8 are the only ones in which $\alpha$ values under 0.05 were not obtained. Results from Q1 and Q4 suggest that knowledge about the content of these two items were already well-known by most of the participants. Question 1 ' ( . . . ) Indicate which of these fish is not present in this river:' and 4 'Characteristic of a lamprey/anatomy' were the questions that the students got right the most before the intervention (34 out of 41 and 37 out of 41, respectively) demonstrating knowledge about the biodiversity associated with the Minho River. In Question 8, on the biology of the otters, there was an improvement of $21.9 \%$ from pre-test to post-test, although just 30 out of 41 (73.1\%) answered correctly after the EE intervention.

Question 12 had the lowest number of correct answers after the intervention. Although there was an improvement after the EE activity, half of the participant answered erroneously to this item (21 students out of 41). This question says: 'There are several reasons that justify the construction of dams. Select the statement that portrays a drawback to the construction of a dam.'. The correct answer would be: 'The decline in environmental services provided by the floodplains downstream.' The negative form of the question may have confused students, and thus may explain this low value.

\subsection{Communication}

\subsubsection{Instagram}

The Instagram profile dedicated to the activities developed by the Cooperminho project had 73 publications from December 2018 to May 2020. The page of this social media had, as of May 2020, a total of 128 followers. The audience reached by Instagram publications was divided into a total of $58 \%$ female and $42 \%$ male (Figure 3 ).

The predominant general age group of Cooperminho social media is 25-34 years old (Figure 3). Among the female audience, the age group of 25-34 years was responsible for $32 \%$ of the audience, and 18-24 years for 29\%. Among male visitors, the 25-34 age group also predominated with $50 \%$ of the public, followed by the $18-24$ age group with $21 \%$ of the target audience. 


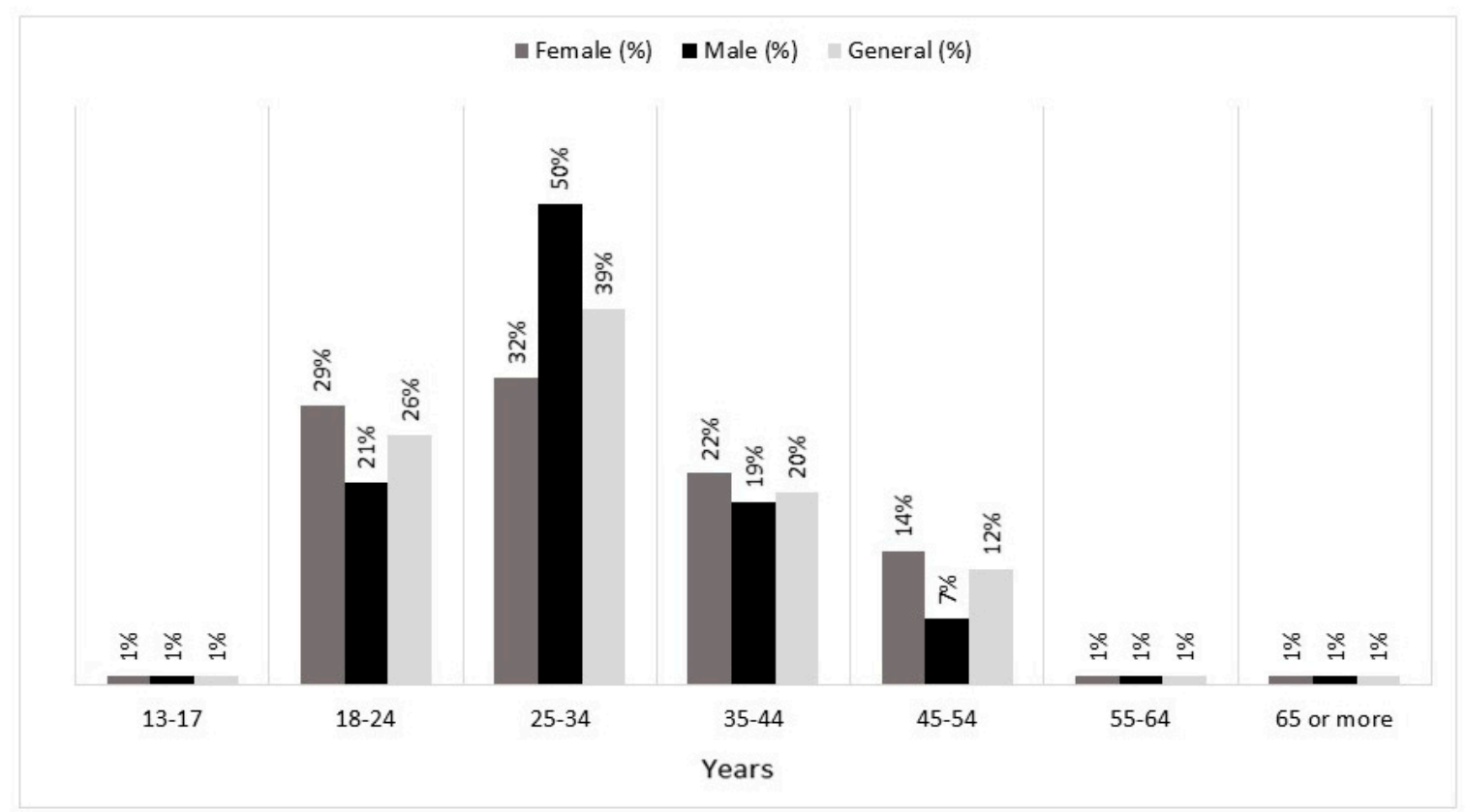

Figure 3. Age distribution of the public of Cooperminho's profile on the Instagram social network by gender and in general (both genders).

The locations of the Instagram audience are presented in Figure 4.

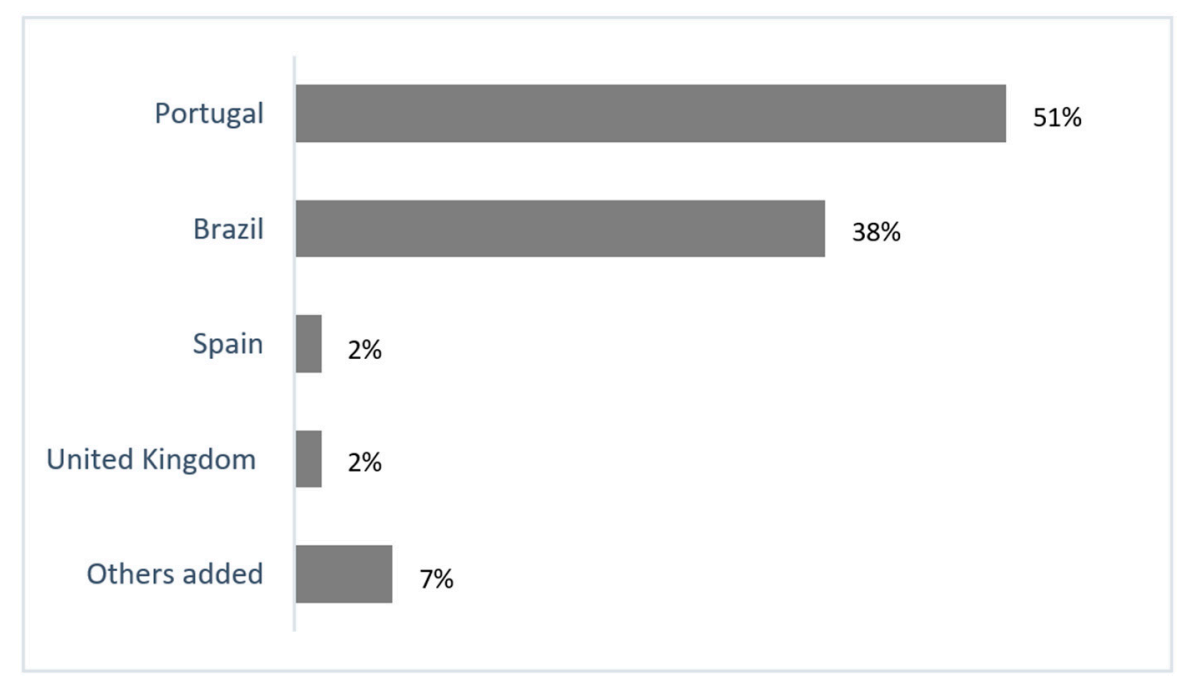

Figure 4. Information about the world public on the Cooperminho Instagram page.

The prominent locations of the Instagram audience (Figure 4) were Portugal (51\%), Brazil (38\%), United Kingdom (2\%), and Spain (2\%). The main municipalities in Portugal included in the total context of views were Porto $(8 \%)$, Aveiro $(7 \%)$, Lisbon $(7 \%)$, and Caminha (3\%).

\subsubsection{Facebook}

The project page on social network Facebook occurred between December 2018 and May 2020 and was analyzed (Table 5). 
Table 5. Summary of the profile of Cooperminho on Facebook.

\begin{tabular}{ccc}
\hline FB Profile Items & Sub-Items & Number \\
\hline \multirow{3}{*}{ I. Account profile } & Publications & 73 \\
& Followers & 568 \\
& Page likes & 561 \\
\hline \multirow{2}{*}{ II. People reaching } & Minimum & 139 \\
& Maximum & 6000 \\
& Average of viewers per publication & $1174.14( \pm 1344.62)$ \\
\hline \multirow{2}{*}{ III. Posts of Photos } & Viewers & 778 \\
& Clicks on publications & 47 \\
& Reactions & 32 \\
\hline \multirow{2}{*}{ IV. Posts of Videos } & Viewers & 607 \\
& Clicks on publications & 62 \\
\hline \multirow{2}{*}{ V. Audience per gender } & Reactions & 31 \\
\hline
\end{tabular}

Seventy-three publications on the general activities of the Cooperminho project were published (Table 5). The project's page on Facebook had 568 followers. The total number of "likes" on the page is 561. The publications reached at least 139 people and at most 6000 people. The average number of people reached per publication was $1174.14( \pm 1344.62)$. The most revered publication was about a short video with the image of the sea lamprey being handled by a local fisher from the Minho region. Publications involving images had an average reach of 778 people, with 47 clicks on publications and 32 reactions, comments, and shares of the publication. The publications involving videos had an average spread of 607 people, with 62 clicks on publications and 31 reactions, comments, and shares of the publication. The individuals reached were $52 \%$ women and $48 \%$ men.

In Figure 5, the information about the female and male audience (age) on the Cooperminho Facebook page until May 2020 is provided.

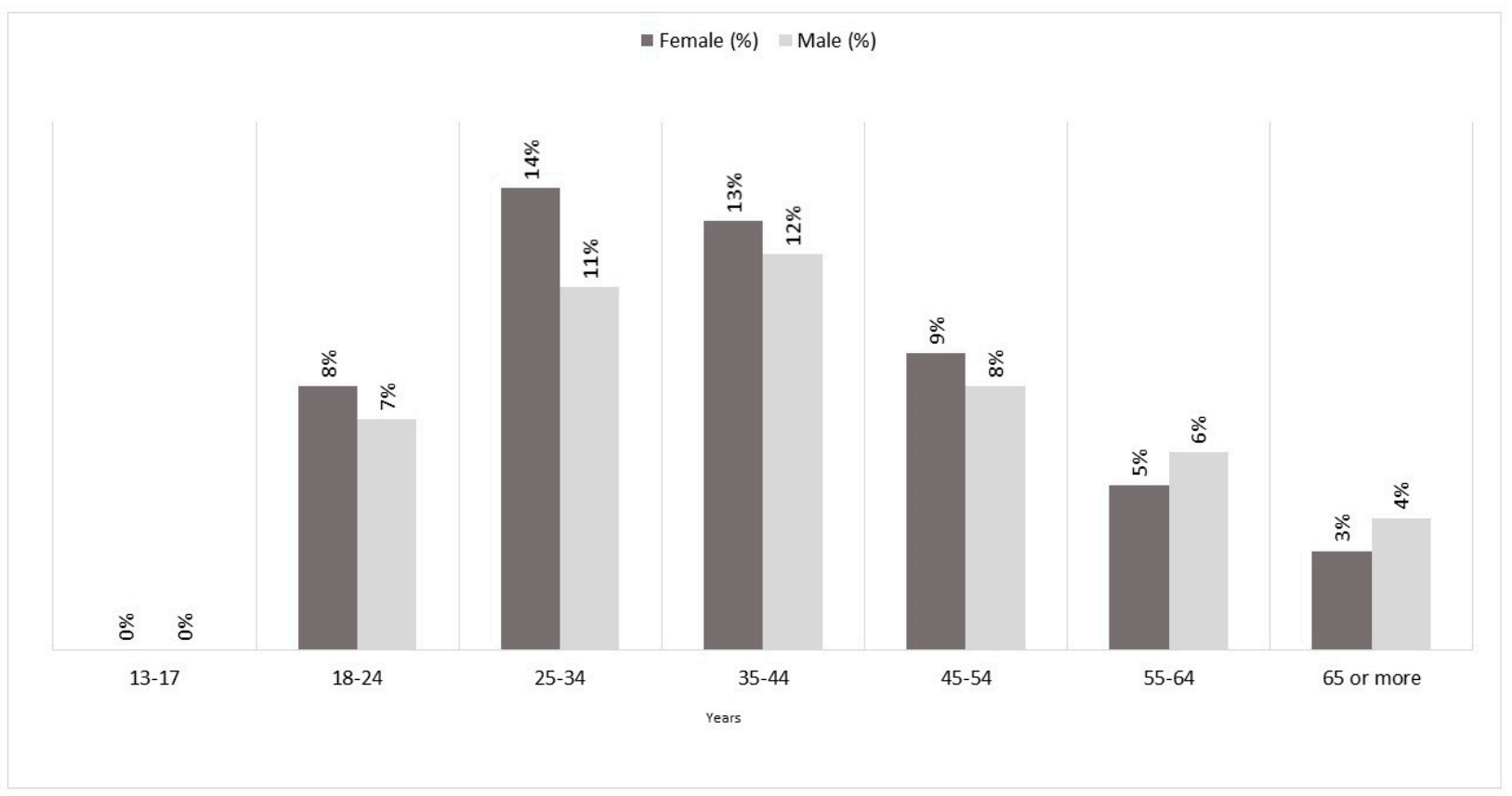

Figure 5. Information about the female and male audience (age) on the Cooperminho Facebook page. 
Of the $52 \%$ that make up the female group (Figure 5), the main groups distributed are the group of 25 to 34 years old (14\%), followed by the age group of 35 to 44 years old (13\%) and the age group of 45 to 54 years old (9\%). Among men (48\%), the highlight was the age group 35-44 years old (12\%), 25-34 years old (11\%), and the age group of $45-54$ (8\%).

The country with the highest reach numbers was Portugal $(n=1492)$, followed by Brazil $(n=95)$, France $(n=68)$, Spain $(n=40)$, and the United Kingdom $(n=15)$. In Portugal, the municipalities with the most followers on the page were Coimbra $(n=256)$, Lisbon $(n=155)$, Caminha $(n=150)$, Braga $(n=108)$, and Viana do Castelo $(n=96)$. In Viana do Castelo District, the highlight goes to Valença $(n=30)$, Vila Praia de Âncora $(n=26)$, Vila Nova de Cerveira $(n=18)$, and Monção $(n=16)$. The followers' languages were predominantly $(n=1564)$ Portuguese, with 1445 from Portugal and 119 from Brazil. The second identified language of the followers was the English of the United Kingdom $(n=67)$. We also identified French $(n=64)$, English from the United States of America $(n=62)$, and languages from Spain $(n=45)$.

The average reach of people by monthly publications is presented in Figure 6.

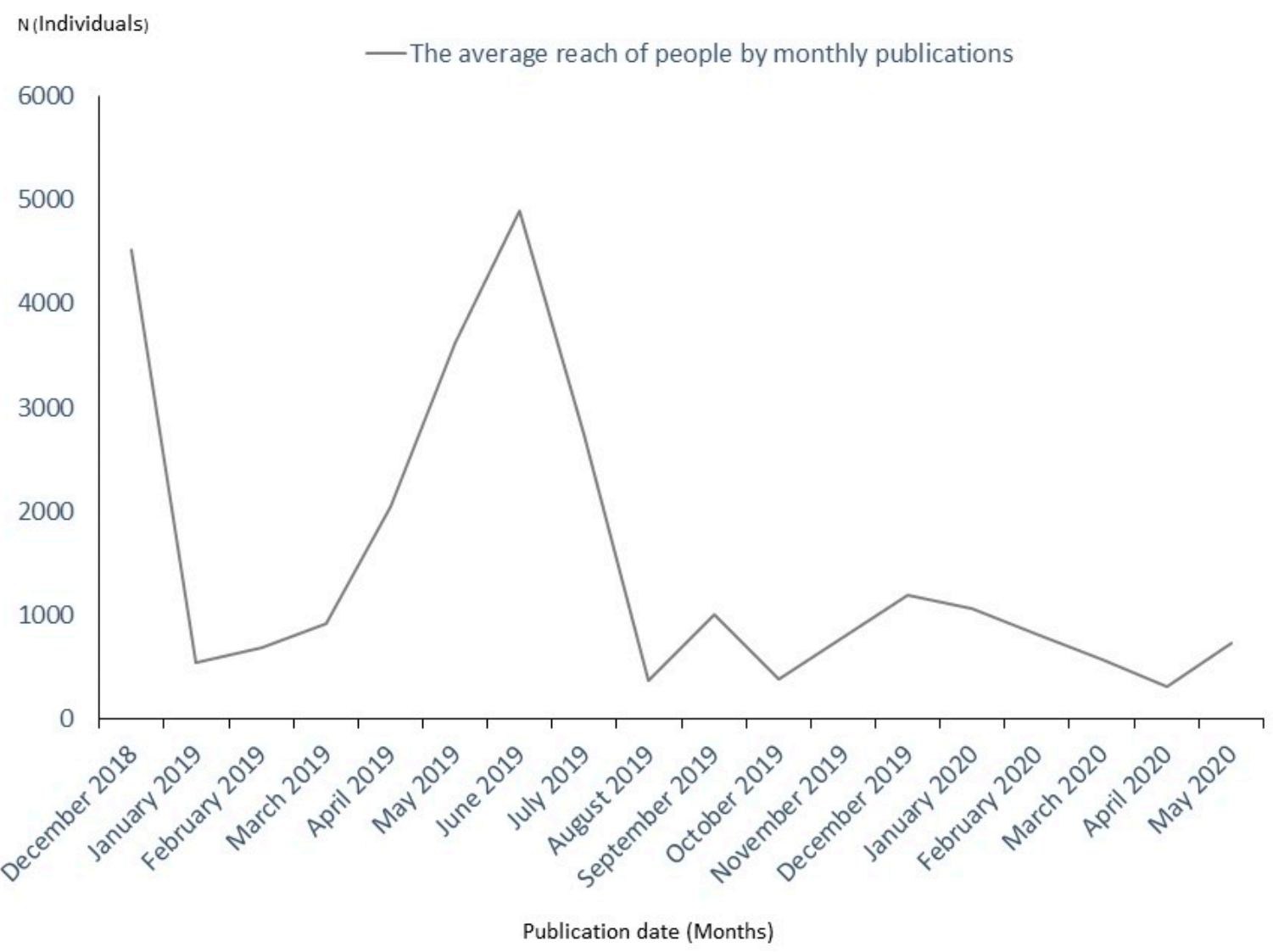

Figure 6. The average reach of people by monthly publications on the Cooperminho Facebook page.

From Figure 6, it is possible to observe that there were about 1000 viewers on the Facebook page, in most of the months of the project. There was an exceptional increment of people mainly between the months of April and July 2019. Two reasons explain this result. On one side, this was a phase with more intense dissemination among fishing associations and groups of the Minho River. On the other side, the Facebook platform offered a promotion to share more widely the posts. The other increment of views (December to March 2020) may have occurred because this is the fishing season of the Sea lamprey and the typical period of this fish offered in local restaurants. Meanwhile, in 2019, there was not a high level of viewers since the Facebook page was just starting. 


\section{Discussion}

\subsection{Environmental Education}

Concerning the intervention of environmental education and OEL with scholars, three main results emerged: An evident increment of OEL; students had some previous knowledge on local estuarine species; and some sub-themes were not assimilated (obstacles to fish such as the dams and sociocultural impacts of the abundance variability of migratory fish for the community).

An evident increment of OEL was detected by a statistically significant difference when comparing the averages obtained by the students before and after the educational intervention (Figure 2 and Table 4). The questions Q3, Q6, Q7, and Q9 had the highest differences. All these questions are related to the ecology of diadromous species, namely with migratory and feeding characteristics of anadromous fish species, such as sea lamprey and allis shad. The relevant increment of knowledge about these species is mainly explained by the enormous motivation of the students. As an example, shared by the educator-scientist, students were asking many questions during the first lecture session and were fascinated with the lamprey's form of feeding - they compared this species with the personage of "vampires", besides a new perspective of the river habitat. Thus, interacting with scientists seems to be a motive and helps in an understanding of ocean and estuarine ecosystems. Furthermore, the educator shared the expectation of the students, in the second session, about the results of the pre-test and post-test. Students felt included and valued, as a crucial part of this study, since the educator had explained their role in the process, from the beginning, and that, in the second session, the results would be presented. The explanation for this knowledge increment is in line with the study of Fauville [41] about students' development of Ocean Literacy when they were "prompted to ask questions to the scientist" (through a virtual laboratory and virtual lecture). Fauville's research demonstrates "how interacting with a scientist gives the students an entry point to the world of natural sciences with its complexity, uncertainty and choices that go beyond the idealised form in which natural sciences often are presented in school" [41] (p. 2151).

Secondly, results show that students already had some previous knowledge on local riverine diadromous species, since in some questions (Table 4), there were no statistically significant differences regarding pre-test and post-test results (with high scores). These questions are related to the ecology of Minho River (Q1), the anatomy of sea lamprey (Q4), and about the biology of one river mammal - the otter (Q8). The results also prove that LEK is not sufficiently valued in the daily classes. Thus, the intervention is a unique opportunity to share those experiences with a scientist. Following Fauville [41], in place of a discussion with a marine scientist, "students get a chance to contextualise and mobilise their preexisting knowledge that they could apply to the field of marine science" [41] (p. 2168). Such existing dynamics among these students are framed by two types of education:

- Non-formal education-regular visits and contacts with the EEF Aquamuseu do Rio Minho, as part of intentional education. The correct answers related to the otter occurred because there is an otter in this aquarium. Besides, a visit was booked to ECOMARE, the Innovation and Sustainability Laboratory of Marine Resources of the University of Aveiro, an infrastructure that connects the port of Aveiro with the coastal lagoon of Ria de Aveiro to help conserve, protect, and ensure the sustainable use of marine resources. The importance of informal education towards an active OEL goes in line with Schubel and Schubel [10] for which this type of educational institutions is more and more committed to "engage, educate and empower the public in moving from ocean" and estuarine "issues to solutions" [10] (this activity was cancelled due to the COVID19 restrictions);

- Informal education - fishing activity with family members and in daily contact with the river habitat and endogenous bioresources. The cultural knowledge and LEK from this fishing community contributes to direct students' knowledge of Minho River and its biodiversity. Cultural knowledge, and Students' local knowledge present a high potential for motivating those students in the curriculum. Besides, Cultural knowledge 
and LEK it is more and more valued by the Portuguese scientific community, such as by Braga et al. [1,2] and Stratoudakis et al. [9]. Moreover, in the first session, students and teachers shared that the fish allis shad is still so common and part of the local culture that the school's canteen offers a typical dish of that fish (Fried shad/Sável Frito) every week.

Thirdly, there were some misconceptions detected related to local ecology fishing activity, such as the dams (Q13) and sociocultural impacts of the stocks' availability/abundance of migratory fish for the community. Students seem to face the dams as an interesting subject. Discussing the fish passes (passages, ladder) in dams was a totally new subject. Another aspect that seems to be unknown or invisible to the students during the sessions is the real importance of the migratory species for the local economy and social structure of many families of that region, following Braga et al. [1,2].

By the misconceptions observed (low scores in the pre-tests and in the post-tests), there may exist a set of obstacles in the educational system regarding ocean and estuarine literacy. Such a result is validated by Fauville et al. [25] who present barriers to teaching 12-19-year-olds about ocean in Europe, including Portugal. These aspects include the need for a national strategy plan to implement ocean and estuarine literacy (OEL); OEL implementation in the curriculum; availability of educational materials and hands-on activities; availability of OEL training course for teachers; and the need to show the importance of ocean in our daily lives (see for more in Fauville et al. [25]). Obstacles and misconceptions may also be related to a traditional educational approach that does not promote the interconnectivity and interdisciplinarity. In the research of Realdon et al. [42] on Ocean Literacy with Italian Primary and Middle school, students demonstrated some misconceptions about ocean dynamics such as the connectedness of all seas and the global dimension of water cycle. To put ocean and estuarine literacy into practice, a pedagogy of interconnectivity in EE becomes relevant, since it allows for the recognition of the interdependence of the local with the global, of society with nature, towards a holistic learning [43].

Nevertheless, in the present and for the future, Portugal and Portuguese authorities are committed to the Ocean Decade, Blue Economy, and a Sustainable Ocean Economy. The National Strategy for the Sea 2021-2030 was recently launched, with one of its strategy goals for the Decade being SG8, to increase Education, Qualification, Culture and Ocean Literacy.

Teachers related to the Education Intervention show a recognition, by the formal education, of scientists' role as transdisciplinary communicators. Teachers value this type of partnership (e.g., "I think we win a lot [with this project] because themes of fauna, flora, icthiofauna are addressed and related to the ethnography (.. ) also with the economic and historical part of the whole municipality.( . . . )" (anonymous teacher); "( . . ) we consider that the interaction between the students (...) and higher education institutions is an added value" (anonymous teacher)). These interventions enhance the knowledge, skills, and attitudes that young people should have, at the end of the compulsory schooling, and areas such as environmental literacy, critical thinking, research, and information processing skills are referred to as a benchmark of the Ministry of Education [44].

\subsection{Communication}

In both types of social media chosen for communicating the project, there were regular dynamics of posting events and news within ocean and estuarine literacy and ethnobiology. The predominant general age group of Cooperminho social media is 25-34 years, which means that this type of platform is adequate for these young adults as well as language. Nevertheless, among other age groups, alternatives of communication forms and language/dynamics may work better.

The low level of users' interaction, namely, on the Facebook page, is in line with other studies [26]. The results may also depend on the type of stories posted or ways of communicating them. Following Fauville et al. [26] and Doney et al. [45], both on social media, the content of stories can potentially increase users' individual interest in science. 
Concerning the gender aspect, the results do not show major differences although women are more presented in both social media. This fact may be explained, like in other environmental areas, by their motivation to conservation initiatives. Furthermore, in global issues like climate change, women are more concerned about the problem, and show greater ecocentric willingness to accept measures to address it [46].

The focus of both social media pages was mainly to reach students, fishermen, education professionals, and other local people from VNC and Portugal. However, due to the globalization of social networks, the visitors included other profiles and locations/geographies, such as Brazilian citizens. This result is partly explained by the main language used on the posts being a common language-Portuguese. Nevertheless, the main reason is due to the presentation in nationals and Portugal-Brazilian congresses, of Cooperminho results concerning the Cultural knowledge, and LEK of artisanal fisheries in Minho River, particularly the sea lamprey. The highlight goes to the VII International Congress of Ethnobotany-I International Congress of Ethnozoology, in Recife, Brazil), one of the major scientific meetings in the world, in the areas of Ethnobiology and Biodiversity conservation.

\section{Conclusions}

Although OEL is on the agenda more than ever, the results of this study, in both areas of environmental education (formal education) and communication (informal education by social media), show the need for a stronger investment on the knowledge concerning migratory fish species and in ocean and estuarine literacy in general. At the same time, it seems to be a growing the motivation to learn more for this kind of projects and for conservation.

Concerning Environmental Education and interpretation on estuary literacy, the intervention of the scientific team had a significant impact due to the scholars' knowledge related to riverine and estuarine ecology and migratory species. It was evident that interactive sessions with scientists motivate students to learn and to integrate their previous informal knowledge. Such integration and environmental interpretation experiences [47] promote the sense of place/river attachment and encourages the adoption of environmentally responsible behaviors in individuals [48]. The fact that the lecture's subjects were focused on a particular setting and not part of a standardized school curriculum may have made the intervention more attractive to the students.

Concerning the Communication aspect, in both types of social media chosen for communicating the project, there were regular dynamics of posting events and topics within ocean and estuarine literacy and Ethnobiology. By the geographical area of the users, it was possible to infer that the scientific community is prevalent compared with other types of users (e.g., from Brazil—Ethnobiology). Therefore, Facebook and Instagram seem to be adequate to communicate with dedicated publics. Nevertheless, the reduced interaction (comments) and the small amount of local and regional users show that these types of social media may not be so adequate and enough to the local community.

This study highlights the need to promote ocean and estuarine literacy in the scope of migratory fish species. The investment on this literacy should use several instruments such as:

- Integrating OEL in formal and non-formal education. "Incorporating interactive ocean science lessons based around the Ocean Literacy into standard school curriculum would be an effective solution to creating a generation of ocean-literate young people (... ) around the world". [11] (p. 106). The discipline of Natural Sciences could be adapted to the community, ecoregion, and geography where the students belong, to associate each theme more easily with the specific region's characteristics, in this case, the Minho River;

- Valuing cultural knowledge and LEK of students and their family members regarding fishing activities. Knowledge and rationalities traditionally ignored by some sectors of the scientific community [49] should also be integrated in the curriculum (e.g., 
plural knowledge and LEK). Results also show the need for embracing other local stakeholders regarding education on socioeconomic aspects of the fishing traditions, in line with Baptista and El-Hani [50];

- Promoting teachers' training in ocean and estuarine literacy, as well as a dialogue with the scientific community. As Mogias et al. [28] found "Pre-service teachers possessed a moderate knowledge of ocean sciences issues and positive attitudes toward ocean stewardship" [28] (p. 251). This means that there is a predisposition and potential of learning and communicate to have ocean literate students. Besides, the education of interconnectivity and training on trans-disciplinarity appear to be a key factor to enhance students with a holistic and systemic OEL [28]. Following Lambert [51], "students of teachers who integrated biological, chemical, geological, and physical characteristics of the oceans performed higher on the content assessment than other students" [51] (p. 633);

- Developing further approaches to this pre-experiment process-quantitative experiments of post-test with several school groups and a control group, as well a qualitative methodological tool as complement. Studies about representations (of students, teachers, parents with fishing activity, and local citizens) on ocean and estuarine realities and on empirical pedagogy of interconnectivity and LEK integration would enforce future strategies on OEL and riverine heritage in the region involved;

- Finally, complementing the communication part of this kind of projects with other social media, more locally focused.

Author Contributions: Conceptualization, S.C.C., M.J.P., and U.M.A.; methodology, S.C.C., M.J.P., and U.M.A.; formal analysis, H.O.B. and A.G.-V.; investigation, S.d.S.-M. and B.F.; writing-original draft preparation, S.C.C. and U.M.A.; writing-review and editing, S.C.C., M.J.P., and U.M.A.; supervision, M.J.P. and U.M.A. All authors have read and agreed to the published version of the manuscript.

Funding: The publication was carried out in the context of the provision of services called "Valorization of the fishing production of the Minho River-contribution to the management and valorization of fishing products of the Minho River (COOPERMINHO) - Communication and socio-environmental training of the Local community for the valorization of the fish resources of the Minho River," financed, via the Municipal Council of Vila Nova de Cerveira, by the program Mar 2020-Programa Operacional Mar 2020 Aviso n`5/2016. The funders had no role in the design of the study; in the collection, analyses, or interpretation of data; in the writing of the manuscript, or in the decision to publish the results.

Institutional Review Board Statement: Data anonymization was assured, and The General Regulation on Data Protection of the UA was informed.

Informed Consent Statement: All the interventions with the students were authorized by the School.

Data Availability Statement: Not applicable.

Acknowledgments: The publication was carried out in the context of the provision of services called "Valorization of the fishing production of the Minho River-contribution to the management and valorization of fishing products of the Minho River (COOPERMINHO)—Communication and socio-environmental training of the Local community for the valorization of the fish resources of the Minho River," financed, via the Municipal Council of Vila Nova de Cerveira, by the program Mar 2020-Programa Operacional Mar 2020 Aviso n` 5/2016. Thanks are due for the financial support to CESAM (UID/AMB/50017/2019), to FCT/MCTES through national funds, and the co-funding by the FEDER, within the PT2020 Partnership Agreement and Compete 2020. This work was also supported by the Fundação para a Ciência e Tecnologia under Grant SFRH/BPD/116379/2016; by the Resclima-EDU Project, funded in the 2018 Call of the State Program of I + D + I, oriented to the Challenges of the Society of the Government of Spain (ref. RTI2018-094074-B-I00). Braga HO thanks the CAPES Foundation-Ministry of Education of Brazil (BEX: 8926/13-1). Authors are grateful to students and teachers from the Escola Básica e Secundária de Vila Nova de Cerveira who collaborated in the success of this research. The authors acknowledge Carlos Antunes for comments to improve the manuscript.

Conflicts of Interest: The authors declare no conflict of interest. 


\section{References}

1. Braga, H.O.; Pereira, M.J.; Morgado, F.; Soares, A.M.; Azeiteiro, U.M. Ethnozoological Knowledge of Traditional Fishing Villages about the Anadromous Sea Lamprey (Petromyzon Marinus) in the Minho River, Portugal. J. Ethnobiol. Ethnomed. 2019, 15, 71. [CrossRef] [PubMed]

2. Braga, H.O.; Pereira, M.J.; Musielo-Fernandes, J.; Morgado, F.; Soares, A.M.; Azeiteiro, U.M. The role of local ecological knowledge for the conservation and sustainable fisheries of the sea lamprey (Petromyzon marinus Linnaeus, 1758) in the Iberian Peninsula. Ocean Coast. Manag. 2020, 198, 105345. [CrossRef]

3. Clemens, B.J.; Arakawa, H.; Baker, C.; Coghlan, S.; Kucheryavyy, A.; Lampman, R.; Lança, M.J.; Mateus, C.S.; Miller, A.; Nazari, H.; et al. Management of anadromous lampreys: Common threats, different approaches. J. Great Lakes Res. 2020, in press. [CrossRef]

4. Azeiteiro, U.M.; Pereira, M.J.; Soares, A.M.; Braga, H.O.; Morgado, F.; Sousa, M.C.; Dias, J.M.; Antunes, C. Dynamics of Two Anadromous Species in a Dam Intersected River: Analysis of Two 100-Year Datasets. Anadromous Fish in a Dam Intersected River. Fishes 2021, 6, 21. [CrossRef]

5. Mota, M.; Rochard, E.; Antunes, C. Status of the Diadromous Fish of the Iberian Peninsula: Past, Present and Trends. Limnetica 2016, 35, 1-18. [CrossRef]

6. Almeida, P.R.; Quintella, B.R.; Mateus, C.S.; Alexandre, C.M.; Pedro, S. Diadromous fish in Portugal: Status, threats and management guidelines. In Sustainable Development of the Ocean: A Necessity; Bebiano, M.J., Guerreiro, J., Carvalho, T., Gameiro, M.I., Eds.; Universidade do Algarve Editora: Faro, Portugal, 2018; pp. 189-213.

7. Carvalho, S.; Azeiteiro, U.M.; Meira-Cartea, P.A. Environmental Education Centres in coastal areas of the Euro region Eixo Atlântico-From conservational to socio-critical models and practices. JICZM J. Integr. Coast. Zone Manag. 2011, 11, $433-450$.

8. United Nations Educational, Scientific and Cultural Organization. Transforming Our World: The 2030 Agenda for Sustainable Development. 2015. Available online: www.sustainabledevelopment.un.org (accessed on 20 September 2020).

9. Stratoudakis, Y.; Correia, C.; Belo, A.F.; Almeida, P.R. Improving participated management under poor fishers' organization: Anadromous fishing in the estuary of Mondego River, Portugal. Mar. Policy 2020, 119, 104049. [CrossRef]

10. Schubel, J.R.; Schubel, K.A. From ocean issues to solutions: The role of public ocean literacy. In Proceedings of the OCEANS 2008, Quebec City, QC, Canada, 15-18 September 2008; pp. 1-7. [CrossRef]

11. Guest, H.; Lotze, H.K.; Wallace, D. Youth and the sea: Ocean literacy in Nova Scotia, Canada. Mar. Policy 2015, 58, 98-107. [CrossRef]

12. Eilam, E.; Trop, T. Environmental Attitudes and Environmental Behavior-Which is the Horse and Which Is the Cart? Sustainability 2012, 4, 2210-2246. [CrossRef]

13. United Nations Educational, Scientific and Cultural Organization. Decade of Ocean Science for Sustainable Development-20212030. 2017. Available online: https:/ / en.unesco.org/ocean-decade (accessed on 20 September 2020).

14. United Nations Educational, Scientific and Cultural Organization. Roadmap for the UN Decade of Ocean Science for Sustainable Development, Version 2.0. 2018. UNESCO. Available online: https:/ /oceandecade.org/resource/44/REVISED-ROADMAPFOR-THE-UN-DECADE--OF-OCEAN-SCIENCE-FOR-SUSTAINABLE-DEVELOPMENT (accessed on 3 March 2021).

15. Ryabinin, V.; Barbière, J.; Haugan, P.; Kullenberg, G.; Smith, N.; McLean, C.; Troisi, A.; Fischer, A.; Aricò, S.; Aarup, T.; et al. The UN Decade of Ocean Science for Sustainable Development. Front. Mar. Sci. ProQuest 2019, 6. [CrossRef]

16. Visbeck, M. Ocean science research is key for a sustainable future. Nat. Commun. 2018, 9, 690. [CrossRef] [PubMed]

17. Schoedinger, S.; Tran, L.U.; Whitley, L. From the principles to the scope and sequence: A brief history of the ocean literacy campaign. NMEA Spec. Rep. 2010, 3, 3-7. Available online: https://coexploration.org/oceanliteracy/NMEA_Report_3/NMEA_ 2010-2-History.pdf (accessed on 3 December 2020).

18. Marrero, M.E.; Payne, D.L.; Breidahl, H. The Case for Collaboration to Foster Global Ocean Literacy. Front. Mar. Sci. 2019, 6. [CrossRef]

19. Carvalho, S.C.; Meira-Cartea, P.A.; Serantes, A.P.; Azeiteiro, U.M. Strengthening Bonds between Environmental Education Facilities: Analysis of Best Practices in the Euro Region of Eixo Atlântico (North of Portugal and Galicia, Spain). Appl. Environ. Educ. Commun. 2018, 18, 266-284. [CrossRef]

20. Lin, Y.-L.; Wu, L.-Y.; Tsai, L.-T.; Chang, C.-C. The Beginning of Marine Sustainability: Preliminary Results of Measuring Students' Marine Knowledge and Ocean Literacy. Sustainability 2020, 12, 7115. [CrossRef]

21. APA-Agência Portuguesa do Ambiente. Estratégia Nacional de Educação Ambiental 2020 [National Strategy of Environmental Education], Agência Portuguesa do Ambiente. 2017. Available online: https://apambiente.pt/_zdata/DESTAQUES/2017 /ENEA/AF_Relatorio_ENEA2020.pdf (accessed on 3 January 2021).

22. Carvalho, S.C.; Meira-Cartea, P.A.; Azeiteiro, U.M. The Trinomial Food-Heritage-Education for Climate Emergency as a Tool for Territorial Innovation. In Handbook of Research on Cultural Heritage and Its Impact on Territory Innovation and Development; Oliveira, L., Amaro, A.C., Melro, A., Eds.; IGI Global: Hershey, PA, USA, 2020.

23. Kapelari, S.; Alexopoulos, G.; Moussouri, T.; Sagmeister, K.J.; Stampfer, F. Food heritage makes a difference: The importance of cultural knowledge for improving education for sustainable food choices. Sustainability 2020, 12, 1509. [CrossRef]

24. Chen, S.; Shao, J. "Have you had your bowl of rice?": A qualitative study of eating patterns in older Taiwanese adults. J. Clin. Nurs. 2012, 21, 2-10. [CrossRef] 
25. Fauville, G.; McHugh, P.; Domgan, C.; Makitalo, A.; Moller, L.F.; Papathanassiou, M.; Chicote, C.A.; Lincoln, S.; Batista, V.; Copejans, E.; et al. Using collective intelligence to identify barriers to teaching 12-19 years old about the ocean in Europe. Mar. Policy 2018, 91, 85-96. [CrossRef]

26. Fauville, G.; Dupont, S.; Thun, S.; Lundin, J. Can Facebook be used to increase scientific literacy? A case study of the Monterey Bay Aquarium Research Institute Facebook page and ocean literacy. Comput. Educ. 2015, 82, 60-73. [CrossRef]

27. Kopke, K.; Black, J.; Dozier, A. Stepping Out of the Ivory Tower for Ocean Literacy. Front. Mar. Sci. 2019, 6. [CrossRef]

28. Mogias, A.; Boubonari, T.; Markos, A.; Kevrekidis, T. Greek Pre-service Teachers' Knowledge of Ocean Sciences Issues and Attitudes toward Ocean Stewardship. J. Environ. Educ. 2015, 46, 251-270. [CrossRef]

29. Costa, S.; Caldeira, R. Bibliometric analysis of ocean literacy: An underrated term in the scientific literature. Mar. Policy 2018, 87, 149-157. [CrossRef]

30. Leitão, R.; Maguire, M.; Turner, S.; Guimarães, L.; Arenas, F. Ocean literacy and information sources: Comparison between pupils in Portugal and the UK. In Proceedings of the INTED2018, 12th International Technology, Education and Development Conference, Valencia, Spain, 5-7 March 2018; pp. 5058-5067.

31. Instituto Nacional de Estatística. Estatísticas Territoriais [Territorial Statistics_Portugal] Instituto Nacional de Estatística [National Institute of Statistics]. 2013. Available online: https://www.ine.pt/xportal/xmain?xpid=INE\&xpgid=ine_unid_territorial\& menuBOUI=13707095\&contexto=ut\&selTab=tab3 (accessed on 3 March 2021).

32. Câmara Municipal de Vila Nova de Cerveira (CMVNC) [City Council of Vila Nova de Cerveira]. Plano de Ação Para a Sustentabilidade Energética. Pacto de Autarcas. Vila Nova de Cerveira [Action Plan for Energy Sustainability. Covenant of Mayors]. 2012. Available online: https://www.cm-vncerveira.pt/cmvncerveira/uploads/writer_file/document/63/PASE_ Plano_de_Acao_Para_Sustentabilidade_Energetica.pdf (accessed on 3 December 2020).

33. Aquamuseu. Aquamuseu Do Rio Minho. Parque de Lazer Do Castelinho. Cerveira: Vila Das Artes. [Aquamuseum of Minho River. Castelinho Leisure Park. Cerveira: Village of Arts]. 2020. Available online: https://aquamuseu.cm-vncerveira.pt/pages/468 (accessed on 20 September 2020).

34. Agrupamento de Escolas de Vila Nova de Cerveira. Perfil, Realidade e Ambição. Agrupamento de Escolas de Vila Nova de Cerveira 2016/2017 [Profile, Reality and Ambition. Grouping of Schools of Vila Nova de Cerveira]. 2017. Available online: http:/ /94.126.169.120/ \{\}ebsvncer/index.php/documentos/send/3-estruturantes/1-perfil-do-agrupamento-2016-2017 (accessed on 20 September 2019).

35. Conselho Local de Ação Social [Local Social Action Council]. Diagnóstico Social Vila Nova de Cerveira 2018 [Social Diagnosis of Vila Nova de Cerveira], CLAS de Vila Nova de Cerveira. 2018. Available online: https://www.cm-vncerveira.pt/cmvncerveira/ uploads/writer_file/document/2683/Diagn_stico_Social_2018.pdf (accessed on 15 September 2020).

36. Bisquerra, R. Métodos de Investigación Educativa—Guía Practica [Methods of Educational Research—Practical Guide]; CEAC: Madrid, Spain, 2000.

37. Sampieri, R.H.; Fernández-Collado, C.; Lucio, P. Metodología de la Investigación [Research Methodology]; McGrawHill: New York, NY, USA, 2006.

38. Miller, L.; Linn, R.; Gronlund, N. Measurement and Assessment in Teaching Pearson; Pearson: New York, NY, USA, 2009.

39. Qaqish, B. Developing multiple choice tests for social work trainings. Train. Dev. Hum. Serv. 2006, 3, 45.

40. Luepsen, H. Comparison of nonparametric analysis of variance methods: A vote for van der Waerden. Commun. Stat. Simul. Comput. 2018, 47, 2547-2576. [CrossRef]

41. Fauville, G. Questions as indicators of Ocean Literacy: Students' online Asynchronous Discussion with a Marine Scientist. Int. J. Sci. Educ. 2017, 39, 2151-2170. [CrossRef]

42. Realdon, G.; Mogias, A.; Fabris, S.; Candussio, G.; Invernizzi, C.; Paris, E. Assessing Ocean Literacy in a sample of Italian primary and middle school students. Rend. Online Soc. Geol. Ital. 2019, 49, 107-112. [CrossRef]

43. Lehtonen, A.; Salonen, A.; Cantell, H.; Riuttanen, L. A Pedagogy of interconnectedness for encountering climate change as a wicked sustainability problem. J. Clean. Prod. 2018, 199, 860-867. [CrossRef]

44. Ministério da Educação [Ministry of Education]. Perfil do Alunos à saída da Escolaridade Obrigatória [Profile of Students Leaving Compulsory Schooling]. Available online: https://dge.mec.pt/sites/default/files/Curriculo/Projeto_Autonomia_e_ Flexibilidade/perfil_dos_alunos.pdf (accessed on 1 May 2021).

45. Doney, J.; Wikle, O.; Martinez, J. Likes, Comments, Views-A content analysis of Academic Library Instagram Posts. Inf. Technol. Libr. 2020, 39. [CrossRef]

46. García-Vinuesa, A.; Iglesias-Cunha, L.; Pernas, R. Diferencias de género en el conocimiento y las percepciones del cambio climático entre adolescentes. Metaanálisis [Gender Differences in Adolescent's Climate Change Knowledge and Perceptions. Meta-Analysis]. Rev. Investig. Educ. Latinoam. 2020, 57, 1-21. [CrossRef]

47. Morales-Miranda, J. A Interpretación do Património (natural e cultural), una disciplina para producir significados [The Interpretation of Heritage (natural and cultural), a discipline to produce meanings]. Ambient. Sustentable Rev. Científica Galego-Lusófona de Educ. Ambient. 2006, 1, 209-220.

48. Vaske, J.; Kobrin, K. Place Attachment and Environmentally Responsible Behavior. J. Environ. Educ. 2001, 32, 16-21. [CrossRef]

49. Alves, F.; Leal-Filho, W.; Araújo, M.J.; Azeiteiro, U.M. Crossing borders and linking plural knowledge: Biodiversity conservation, ecosystem services and human well-being. Int. J. Innov. Sustain. Dev. 2013, 7, 111-125. [CrossRef] 
50. Baptista, G.C.; El-Hani, C.N. The contribution of ethnobiology to the construction of a dialogue between ways of knowing: A case study in a Brazilian public high school. Sci. Educ. 2009, 18, 503-520. [CrossRef]

51. Lambert, J. High School Marine Science and Scientific Literacy: The promise of an integrated science course. Int. J. Sci. Educ. 2006, 28, 633-654. [CrossRef] 